\title{
Effects of X-ray irradiation on methylation levels of p16, MGMT and APC genes in sporadic colorectal carcinoma and corresponding normal colonic mucosa
}

\author{
Łukasz Krakowczyk ${ }^{1,3^{*}}$, Joanna K Strzelczyk ${ }^{3}$, Sławomir Blamek², Adam Maciejewski', Stanisław Półtorak', \\ Andrzej Wiczkowski ${ }^{3}$
}

From Annual Conference on Hereditary Cancers 2011

Szczecin, Poland. 17-18 November 2011

Colorectal cancer, one of the most aggressive cancers, occurs with a high incidence in all over the world. Cancer development and progression is dictated by series of alterations in a number genes such as tumor suppressor genes, DNA repair genes, oncogenes and others. DNA methylation is an epigenetic modification that is profoundly altered in most cancers. Radiation is a wellknown genotoxic agent and human carcinogen that gives rise to a variety of long-term effects. The inheritance of genomic instability suggests the possible involvement of epigenetic mechanisms, such as changes of methylation of the cytosine residues located within CpG dinucleotides. In the current study we evaluated the effect of $\mathrm{X}$-ray irridiation on methylation levels of p16, MGMT and APC genes in colorectal cancers and normal colonic mucosae. Fresh tissue samples were obtained from 26 patients (age of 26 to 81 years) with primary colorectal adenocarcinoma and corresponding normal tissues. We used methylation-specific polymerase chain reaction (MSP) for analysis of the methylation status of $\mathrm{p} 16$, MGMT and APC1A, APC1B genes. Methylation of p16, MGMT, APC1A and APC1B was detected in 42\%, 67\%, $42 \%$ and $20 \%$ of tumors before X-ray irradiation and in $63 \%, 56 \%, 25 \%$ and $31 \%$ after radiotherapy, respectively. In corresponding normal colonic mucosa methylation of p16, MGMT and APC1A was detected in 17\%, 25\% and $8 \%$ before and in $19 \%, 31 \%$ and $6 \%$ after irradiation,

\footnotetext{
* Correspondence: lukaszkrakowczyk@wp.pl

${ }^{1}$ Maria Sklodowska-Curie Memorial Cancer Center and Institute of Oncology, Gliwice Branch Department of Oncological and Reconstructive Surgery, Poland

Full list of author information is available at the end of the article
}

respectively. Differences between groups, although noticeable did not however reach the level of statistical significance.

\section{Author details}

${ }^{1}$ Maria Sklodowska-Curie Memorial Cancer Center and Institute of Oncology, Gliwice Branch Department of Oncological and Reconstructive Surgery, Poland. ${ }^{2}$ Maria Sklodowska-Curie Memorial Cancer Center and Institute of Oncology, Gliwice Branch Department of Radiotherapy, Poland. ${ }^{3}$ Medical University of Silesia in Katowice, Department of General Biology, Zabrze, Poland.

Published: 20 April 2012

doi:10.1186/1897-4287-10-S3-A12

Cite this article as: Krakowczyk et al:: Effects of X-ray irradiation on methylation levels of p16, MGMT and APC genes in sporadic colorectal carcinoma and corresponding normal colonic mucosa. Hereditary Cancer in Clinical Practice 2012 10(Suppl 3):A12.

Submit your next manuscript to BioMed Central and take full advantage of:

- Convenient online submission

- Thorough peer review

- No space constraints or color figure charges

- Immediate publication on acceptance

- Inclusion in PubMed, CAS, Scopus and Google Scholar

- Research which is freely available for redistribution

\section{Biomed Central}

